\title{
A SHORT HISTORY OF EIGHTY YEARS OF LIMNOLOGY IN SPAIN
}

\author{
S. Casado and C. Montes \\ Laboratorio de Limnología. Departamento de Ecología. Universidad Autónoma de Madrid. 28049 Madrid. Spain.
}

Keywords: History of ecology, History of limnology, Laboratorio de Hidrobiología Española, Spain.

\begin{abstract}
Historically both socioeconomical and ideological constraints have prevented a normal development of science in Spain Ecological sciences such as limnology had in the past problems to attain an appropriate institutional framework, which only very recently has been created. In this context, special attention is deserved for early scientific projects in ecology such as that of Celso Arévalo, founder of the first center devoted to limnological research in Spain, the Laboratorio de Hidrobiología Española, in Valencia in 1912. Arévalo's approach was partially continued by his collaborator Luis Pardo at the Sección de Biología de las Aguas Continentales, in Madrid, which was one of the scientific centers asociated to the Corps of Forestry Engineers. After the Civil War of 1936 an important new period for limnology started with the works of Ramon Margalef, eventually resulting in a normalization of this science in Spain during the decades of the 1970's and 1980's.
\end{abstract}

\section{INTRODUCTION}

In 1912, eighty years ago, Celso Arévalo created in Valencia the Laboratorio Hidrobiológico, later called Laboratorio de Hidrobiología Española, which was the first center, and for many years the only one, devoted to limnological research in Spain. The word "limnology" reachs its centenary in 1992 and the international congress of limnology will be held in Spain this year. This anniversary is a good opportunity to look back to that early period of Spanish limnology, lasting until the Civil War of 1936, which to a large extent has remained unknown to most of the people involved in the development of limnology in Spain during the last two decades. Indeed, no attempt has been made to give a historical overview of Spanish limno$\operatorname{logy}$. The aim of this article is to provide a short account of this history, with special attention to the early times of limnological research, as an introduction to the curretit state of limnology in Spain, which is presented in detail in other contributions of this volutne.

Knowledge of previous periods of Spanish limtrology is bound to supply useful information to present day researchers working in the area of aquatic ecology in Spain, both on the historical constraints that have affected its develop- ment and on the conceptual background that explains our current approach in studying rivers, lakes and wetlands.

Economic, social and also ideological limitations have historically prevented a normal development of science in Spain as compared to other Western Europe countries, ecological science being no exception. In spite of the remarkable process of modernization and improvement of scientific research that took place in Spain during the first third of twentieth century, ecology had a very limited reception in the small Spanish scientific community and suffered an almost complete lack of specialized centers in the institutional framework of science and research. The ecological approach was accepted by most Spanish naturalists of this period at a theoretical level but only occasionally was it used in specific scientific research. Lack of specialization resulted, with few though remarkable exceptions, in very poor standards in ecological research, a situation that remained unchanged throughout the first half of the century. Only the early works of Ramon Margalef around 1945, devoted mostly to limnology of Iberian lakes and wetlands, involved a more ambitious approach to ecological research, as well as the first serious attempt to obtain a reasonable level of taxonomic and ecological knowledge of the species and communities of organisms of Spanish continental aquatic 
ecosystems. Yet, the failures and achievements of the early period of Spanish limnology are worth examining in some detail, both as a part of the general picture of science in Spain at the begining of the century and as a basis and historical background to what is being done today in the same scientific and geographical area.

\section{FIRST BIOLOGICAL AND GEOGRAPHICAL STUDIES ABOUT SPANISH CONTINENTAL WATERS}

Prior to 1912 there were no truly limnological research projects in Spain. Some scientifíc activities related with aquatic groups of organisms must be mentioned but even those investigations were few and scattered in time. During most of nineteenth century natural history went through a critical, dark period in Spain. The Iberian peninsula became a favourite collecting ground for foreign naturalists, coming from other European countries, who found here a largely unexplored and very rich natural territory, whereas national scientific production was extremely limited (GOMIS BLANCO, 1988).

Specific methodological requirements for collecting and identifying aquatic organisms prevented even more its study'by Spanish naturalists. Only occasionally aquatic species of insects or plants and macroscopic algae appeared in local or regional taxonomic inventories made by Spanish zoologists and botanists. Yet, some aquatic groups with special appeal because of their morphological variety received some specific attention, such as freshwater molluscs (GRAELLS, 1846; MACHO VELADO, 1878) or diatoms. In fact, diatoms reached a certain popularity among Spanish microscopists, the first record of a living diatom collected in Spain appearing as early as 1824 (AZPEITIA, 1908). But this scientific interest only focussed on taxonomic and morphological aspects, without any relation with the study of aquatic habitats, as it can be inferred from the equal interest for fossil or living specimens shown by early Spanish diatomologists as Alfredo Truan (1833-1890), Florentino Azpeitia (1859-1934) or Ernesto Caballero (1858-1935). Other groups of microscopic algae received almost no attention during that time.

Freshwater malacology was particularly developed in Catalonia, with the works of Manuel de Chia (1856-1917), Artur Bofill (1846-1929) and Joan Baptista d' Aguilar-Amat (1882-1936). During the World War of 1914 this Catalonian school of malacologists was joined by German specialist F.
Haas, who did a very valuable work in collaboration with local naturalists.

Ichthyology must also be mentioned because of some valuable works containing information about the fishes of Spanish rivers and wetlands and related environmental observations, as that of CISTERNAS (1887) on the continental ichthyofauna of the Valencia region. In relation to this it is interesting to note the early developments of aquiculture made by Mariano de la Paz Graells (1809-1898), who wrote a whole book on the subject (GRAELLS, 1864) and created the first fish farming installation in Spain at La Granja, Segovia, in 1866. As will be seen later, ichthyology and fish farming played an important role in the first stages of institutional development of limnology in Spain.

From a different point of view, other naturalists, such as geologist Salvador Calderón (1851-1911), became interested in the "steppic" features of Iberian landscape, including saline wetlands. Calderón, who studied the saline minerals of Spain, did geological research, postulated geochemical explanations about the origin of these saline wetlands and collected specimens of their peculiar biota (CALDERON, 1888, 1889). Botanist Eduardo Reyes Prósper (1860-1920) also directed his attention towards the steppic flora of Central and Southern Spain regions, following the geobotanical interpretation of Iberian vegetation first proposed by WILLKOMM (1852). He published a monograph on the Charophyta of Spain, "particularly those growing in its steppes" (REYES PROSPER, 1910), and a general description of Spanish "steppic" flora, soils and wetlands (REYES PROSPER, 1915).

Mountain lakes associated to glacial morphology also attracted the attention of some naturalists. In 1912, an important year in the history of Spanish limnology for several reasons, two different scientific expeditions surveyed Sanabria lake, in Northwestern Spain. The first expedition was led by German geographer W. Halbfass, who took detailed measurements of lake morphology and temperature and sampled phytoplankton. Some weeks later Spanish naturalist José Taboada made similar observations. The works of TABOADA TUNDIDOR (1913) and HALBFASS (1913), even though both dealt mainly with physical features, were the first truly limnological studies carried out in Spain to be published.

Nevertheless, the dominating feature of this early period was an overwhelming lack of original research and reliable information on aquatic biota and ecological features of Iberian continental waters. For example, at the end of nineteenth century faunistic data of such an important group as 
crustaceans hardly included more than half a dozen species scattered in a few localities (BUEN, 1887). Only in the decade of 1950 's, with the works of Margalef, a general knowledge of Spanish aquatic communities would be reached.

A number of associations were created precisely to tackle these scientific gaps of Spanish natural history, such as the Sociedad Española de Historia Natural, the Institució Catalana d'Història Natural or the Sociedad Aragonesa de Ciencias Naturales. The first and most important of this associations of naturalists was the Sociedad Española de Historia Natural, founded in 1871. One of the major achievements of this group of scientists was the creation in 1886 of the Estación de Biología Marítima, in Santander, the first oceanographical center established in Spain.

\section{CELSO AREVALO AND THE LABORATORIO DE HIDROBIOLOGIA ESPAÑOLA}

As a young graduate Celso Arévalo (1885-1944) obtained two scholarships for training periods at the Estación de Biología Marítima in 1904 and 1905. In 1912, when Arévalo became Professor of Natural History of the Instituto General y Técnico de Valencia, a secondary school center, he decided to establish a hydrobiological laboratory there. In doing this Arévalo was influenced not only by his training at a coastal biological station but also by his knowledge of limnological stations placed at the shore of lakes in different European countries, which were taken as a model for his project. The city of Valencia is located next to an important coastal lagoon, named L'Albufera, and Arévalo, who was an ambitious and gifted young scientist, saw the opportunity to introduce his country to a kind of study that had not been developed at that time in Spain. Arévalo's project was in fact the first ecologically oriented resarch programme to be initiated in Spain, a merit that has received almost no recognition in recent times. Only MARGALEF (1983) and CAMARASA (1989) mention the work of Arévalo, though only regarding it with limited interest.

It must be recognized that the scientific results of the hydrobiological laboratory were not as satisfactory as Arévalo had first intended. Several reasons can be pointed out to explain this partial failure when examining the history of the laboratory (AREVALO, 1914, 1929; PARDO, 1942, 1945, 1952). First, the lack of official and financial support, resulting in practical problems of all kinds. No full time senior research post was ever obtained for the laboratory. In
1912, when Arévalo placed some scientific tools at a corridor of the Instituto, the Laboratorio Hidrobiológico was just a personal project of his. In 1914 the laboratory was officially incorporated as a department of the Instituto General y Técnico de Valencia. In 1916 Arévalo promoted the publication of a journal, Anales del Instituto General y Técnico de Valencia, including a scientific series of "hydrobiological works", of which 33 were published up to 1928. Finally, in 1917, due to the prestige gained by Arévalo during those years, the government gave the laboratory the status of a national research center, with the name of Laboratorio de Hidrobiología Española. But no funds were delivered nor suitable rooms and equipment were provided for the new center.

Another kind of problem seems to have been related with the reluctance shown by the Spanish community of naturalists to accept an ecological research project such as Arévalo's. With so much yet to be done in order to complete the taxonomic and geographical knowledge of Iberian fauna and flora it seemed that ecology was not a priority.

In 1919 Arévalo moved to the Instituto del Cardenal Cisneros, in Madrid, always as a Professor of Natural History. Then, in the most important national research center in the field of natural sciences, the Museo de Ciencias Naturales, a new section devoted to hydrobiology was created for him. The laboratory was mantained in Valencia as a field station associated to this new hydrobiological section of the museum. Luis Pardo (1897-1957), a disciple of Arévalo who had become his closest collaborator, was designated keeper of the laboratory, with a status of assistant researcher paid by the museum. In Madrid, another assistant researcher, Manuel Ferrer Galdiano was also incorporated into the hydrobiological section, suposedly to help Arévalo in his ecological work. Instead, Ferrer Galdiano's work was devoted mostly to the taxonomy of freshwater crustaceans and no financial support was given to Arévalo and neither to Pardo. Personal conflicts between Arévalo and other researchers at the Museo de Ciencias Naturales could also have been influential in this situation, that ended in 1932 when the hydrobiological section of the museum was finally removed. Earlier, in 1928, Pardo had moved to Madrid for another job and the laboratory in Valencia had virtually ceased to exist.

During the first years in Valencia Arévalo had concentrated on the study of plankton at L'Albufera lagoon (AREVALO, 1916, 1917), an endevour that required considerable effort in solving methodological and taxonomical problems, considering that there was no previous experience 
in Spain. Twenty years after F. A. Forel had first proposed the word limnology, but ten years before E. Naumann and A. Thienemann created the SIL, Arêvalo tried to fill the gap in Spanish science as far as limnology was concerned. Not only did he work in taxonomical and ecological studies but he also made some theoretical and conceptual work, striving to establish a "hydrobiology", the word he chose (AREVALO, 1921), with a conceptual framework that was fit for Spanish aquatic ecosystems, quite different from those of Central Europe and Eastern North America, where limnology had been developed for the most part.

Whereas oceanography had received some support in Spain from governmental authorities (the Instituto Español de Oceanografía was founded in 1914, grouping several already existing coastal stations) small Spanish rivers and wetlands, with temporary and fluctuating regimes typical of semiarid climates, seemed of little economic and scientific interest to the politicians and leading scientists. Trying to get financial and institutional support for his project, Arévalo claimed that, though not comparable in size or volume to the lakes and rivers of other countries, Spanish continental waters had their own scientific and economic values (AREVALO, 1921).

A good knowledge of leading scientific languages, especially German, and contacts with most important limnological centers of Europe, some of which he visited personally in France, Belgium, Italy, Switzerland and Germany, made it possible for Arévalo to have a sound and up to date knowledge of the main trends of limnology of that period, being himself particularly influenced by Thienemann's work. Arévalo attended several SIL congresses and was designated SIL delegate in Spain. Another source of international contacts for Arévalo was the presence of foreign scientists in Spain seeking a safe place to stay during the First World War of 1914. Among them there were several researchers who took advantage of Arévalo's laboratory in Valencia, as Swiss ichthyologist spccialized in eel A. Gandolfi, German malacologist F. Haas and, indirectly, German specialist in Hydracarina K. Viets. Part of their papers based on Spanish specimens can be found among the "hydrobiological works" published in the Anales del Instituto General y Técnico de Valencia, the journal of the center where the laboratory was located.

Once in Madrid, integrated in such an important center as the Museo de Ciencias Naturales, Arévalo thought it was time to adopt a more ecological approach to his work, focusing on what he had always regarded as a central issue in limnology, temporal and spatial variation of plankton communities, what he did studying a pond placed in a public park in Madrid (AREVALO, 1923a). But the isolated position of Arévalo in the Spanish scientific community, and specially in the museum, was made evident when he attempted to organize a limnological survey of a lake distant from Madrid, Carucedo lake. The expedition to Carucedo lake, due to very limited financial and technical support, produced poor scientific results (AREVALO, 1923b). This virtually meant the end of Arévalo's limnological project. A final product of that project was his book La vida en las aguas dulces (1929), the first general treatise on limnology to be published in Spain, and, in spite of his popularizing approach, an interesting work that includes in a summarized form many of his observations on Spanish wetlands and lakes.

Meanwhile Luis Pardo had moved to Madrid to work as editor of the Boletín de Caza y Pesca, an official journal devoted to hunting and fishing issues, where he published many bibliographical notes on aquatic ecosystems and their biota. Pardo kept Arévalo's idea of promoting the ecological study of Spanish continental waters and the assessment of their natural resources and he worked hard to support and popularize this view throughout his life.

\section{LUIS PARDO AND THE SECCION DE BIOLOGIA DE LAS AGUAS CONTINENTALES}

The participation of Forestry Engineers in the history of Spanish limnology is strongly related to applied ichthyology. The direction of the first fish farming installation, created in 1866 by zoologist Graells as we have already seen, was soon undertaken by Forestry Engineer Rafael Breñosa (1835-1916). Since then management of fishing resources of continental waters was a duty officially assigned to the Corps of Forestry Engineers. In 1929 the Laboratorio de la Fauna Forestal, Piscicultura y Ornitología, created in 1918 with the shorter name of Laboratorio de la Fauna Forestal Española, published the first issue of a journal entitled Revista de Biología Forestal y Limnología, of which several issues appeared containig various papers on Spanish ichthyofauna. In 1931 this laboratory was incorporated into the Instituto Forestal de Investigaciones y Experiencias, a center that grouped together all official forestry research activities. A special section devoted to limnology was then created, called Sección de Biología de las Aguas Continentales (PARDO, 1949), soon joined by Luis Pardo, who brought with him his important specialized library as well as valuable files with geographical, faunistic and floristic 
data resulting from Pardo's previous dedication to limnological studies.

The Sección de Biología de las Aguas Continentales, directed by Forestry Engineer Luis Vélaz de Medrano, got its own building as well as an experimental fish farming installation, both built during the years 1932 to 1934 close to the Manzanares river, in the outskirts of Madrid. The most important scientific result of this center was precisely a limnological monograph of the Manzanares river (VELAZ DE MEDRAN0 \& UGARTE, 1933), in which physicochemical and biological data were used to explain the distribution of fish communities along the stream. Several other papers, mainly dealing with ichthyology and fish farming subjects, were also published during this period, lasting until 1936, when the Spanish Civil War began.

With General Franco's troops close to the area where the center was placed, Vélaz de Medrano tried to move the section to a safer location, but local military authorities denied the permission. Eventually, the scientific and assistant staff was forced to leave the building and uncontrolled groups stole and completely destroyed the library, files and tools (PARDO, 1949). Because of this destruction it is difficult to evaluate how great the scientific potential of this center would have been.

At any rate, the Civil War interrupted an important process of modernization of Spanish science, not only regarding natural sciences but most aspects of culture and knowledge. It also meant, in the last instance, the end of the limnological tradition initiated by Arévalo. In spite of the enthusiasm that Pardo showed repeatedly for Franco's new regime and the officially claimed new era of scientific progress, and even though some research was carried out in the Sección de Biología de las Aguas Continentales after 1939 , when the war was finished, the reality is that original scientific work in limnology was almost non-existent, as well as in many other fields of Spanish science.

Paradoxically, some naturalists who had been working in oceanographical sciences shifted to limnology when, forced by the adverse results of the war, went into exile and settled in Latin America, especially in México (REYES NEVARES, 1982), a country rich in lakes. This is the case of Enrique Rioja (1895-1963), a leading specialist in marine benthic groups when working in Spain, who later dealt also with continental aquatic organisms in México, where he was chief of the department of hydrobiology at México University. Fernando de Buen (1895-1962) worked first as ichthyologist at the Instituto Español de Oceanografía and was later involved in the development of Mexican limnology since he worked for several years at the Estación Limnológica de Pátzcuaro.

In Spain, Pardo published many articles, monographs and books mostly devoted to applied issues. The most interesting of these publications is a comprehensive monograph on L'Albufera (PARDO, 1942), the lagoon in which Spanish limnology had started thirty years before. In this monograph Pardo explicitly adopted the same descriptive approach that Forel had initiated with his study of lake Léman, but introducing also human aspects, both cultural and economical, as an important part of the description of the ecosystem, giving a full account of the history of human populations in the area and their relationship with the natural resources of L'Albufera. In doing this he established a very interesting approach, related to a modern concern for human activities as an integral part of ecosystems, particularly regarding the role of local people in the traditional management of natural resources. But, at the same time, Pardo's descriptive work, based mostly on bibliographical data, lacked a truly ecological approach. Another valuable contribution of Pardo, again based almost entirely in bibliographical research, was his catalogue of Spanish "lakes" (PARDO 1948), in which he compiled very complete and useful information on lakes, ponds and wetlands, both natural and man made, that even today is still a main source of data, and often the only one when lost ecosystems are concerned, on Spanish lacustrine and palustrine heritage.

But it was a young naturalist from Barcelona named Ramon Margalef, at that time begining his career as a scientist, who would start a completely new phase, building the scientific basis for a regional limnology of Iberian continental waters and thus making possible the later development of limnological studies in Spain. Yet, even though Margalef's work virtually meant a new birth of limnology in Spain, some cbnnections with the previous phase did exist. As an incidental example, one of Margalef's most important early limnological contributions (MARGALEF, 1955) was published precisely by the Instituto Forestal de Investigaciones y Experiencias.

Before briefly analyzing what could be called the modern period of limnology of Spain, intimately associated to Margalef, we must mention other scientists, trained in the years before the war, who faced difficult times for scientific activity in Spain during their careers and yet made some valuable, even when modest, contributions. Geographer Juan Dantín (1881-1943) became interested in the "endorheic" character of semiarid regions of the Iberian peninsula, studying from a physiographical point of view many of the saline and fresh 

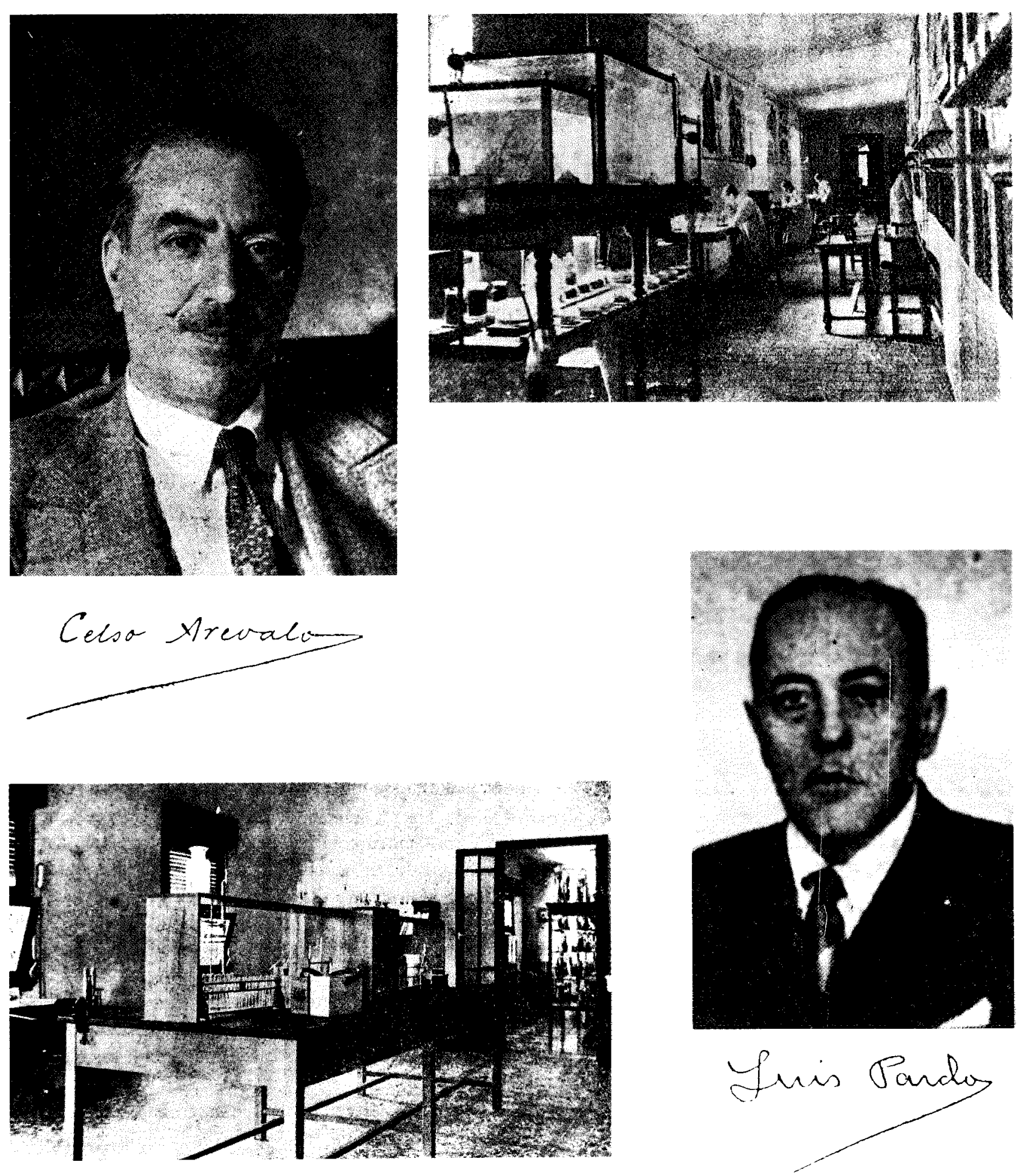

Figure 1. Scientists and scientific centers ot the early period of Spanish limnology. Left top, Celso Arévalo. Right top, the Laboi-atory of Hidrobiology in the Instituto de Valencia. Lefi bottom. The laboratory of ecology in the Sección de Biología de las Aguas Continentales. Right bottom, Luis Pardo. 
water wetlands typical of these areas (DANTIN CERECEDA, 1929, 1930). Pedro González Guerrero (1902-1984) was one the first Spanish specialists in microscopic algae of continental waters and developed a considerable work on these groups which can be found in his numerous publications (ALVAREZ COBELAS \& GALLARDO. 1985).

\section{RAMON MARGALEF AND THE MODERN PERIOD OF LIMNOLOGY IN SPAIN}

Ramon Margalef (1919) became interested in the study of nature when he was very young. The Civil War prevented the normal development of his scientific career, so it was not until the 1940's when Margalef was introduced to the scientific institutions in Barcelona and began publishing his research on aquatic biota. His studies, devoted mostly to marine and continental plankton. soon acquired an ecological perspective that Margalef developed to its fullest extent

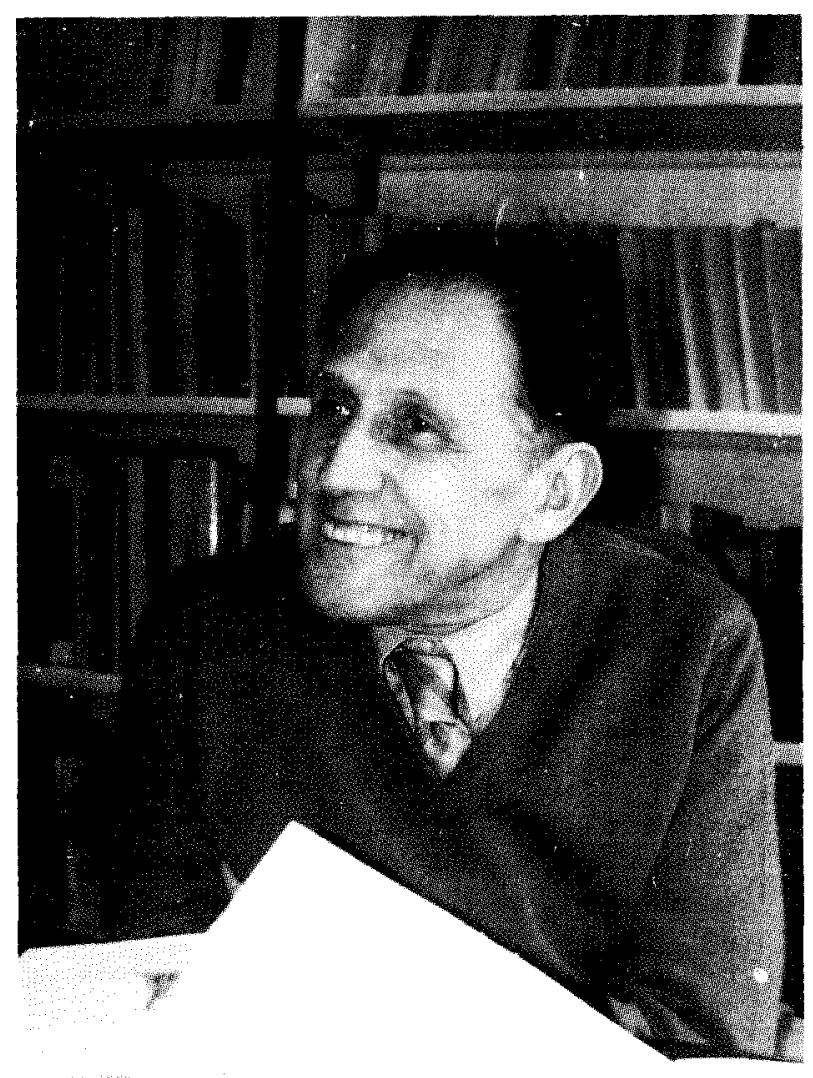

Figure 2. Ramon Matratel. Lounder of the modern period of linmology in Spain. in the ensuing years, resulting in his excellent work of synthesis Los organismos indicadores en lo Limnología (MARGALEF, 1955). This was the naturalist period of Margalef's work. in which he surveyed the aquatic ecosystmes of the Iberian peninsula, building up a regional limnology similar in its approach to those that were being devcloped in Central Europe.

In 1951 he had started to work at the Instituto de Investigaciones Pesqueras, in Barcelona, which he later directed, and thus much of his rescarch was focused on marine ecology. During this period Margalef also became interested in theoretical ecology. His well known contributions in this field have had a very important international impact and are far beyond the scope of this paper. Anyhow, Margalef retained a deep interest in basic limnological research.

In 1967 Margalef became the first Professor of Ecology and Director of the first Department of Ecology of Spanish university. which was created in the Universitat de Barcelona. In this center a true limnological school was at last formed around Margalef. During the decade of the 1970's an important group of young researchers were trained in the study of karstic and mountain lakes, coastal lagoons, rivers and reservars. These limnologists subsequenty formed new research groups in other Spanish universities. Finally, an specialized journal also appeared, Oecologia aquatica, which was published in Barcelona since 1973, devoted 10 limnology and oceanography grouped together under the concept of aquatic ecology.

The publication of Margalef's book Limnologia in 1983. which completed his ecological corpus which started in 1974 with Ecologia, means the maturity of Margalef as a limnologist and of limnology as a firmly established science in Spain.

The creation of the Asociación Española de Limnología in 1981 also had an important significance in the normalization process of this science in Spain. Up until this time, there had been numerous groups of people, mainly in zoology departments of different faculties, who worked independently from those of the Universitat de Barcelona and in a more or less isolated and self-taught way on taxonomy of aquatic organisms and biological indication of water quality. During the 1970's a certain degree of concern about pollution in Spanish rivers grew among governmental authorities and funds were provided for research in this field. As a result some research groups appeared in different regions of Spain. The Asociación Española de Limnología connected these previously isolated efforts and with its scientific meetings and publications provided means for communication and exchange of ideas and experiences 
among Spanish limnologists. Recently an official scientific center, the Centro de Investigaciones del Agua, in Arganda, Madrid, has been reactivated and hopefully it will contribute to the growth and development of Spanish limnology.

Today we can claim that limnology, as a basic science, is firmly established in Spain. An association exists with more than 300 members, an international scientific journal, Limnetica, and a newsletter bulletin, Alquihla. Bibliographical checklists and identification keys of aquatic fauna and flora are published by the association and national congresses are held every two years. Limnology is taught in 6 different universities and an international course takes place periodically in the Centro Internacional de Altos Estudios Agronómicos, at Zaragoza. Finally, the 1992 edition of SIL congress will be held this year in Barcelona. In a way, this event can be regarded as international recognition of the work done during the last eighty years by limnologists in Spain.

\section{CONCLUDING REMARKS}

As any other social or cultural process, limnological science in Spain has followed a historical path parallel to political and economical factors that, since nineteenth century, have conditioned strongly its development. In this regard, limnology shares some historical patterns with other sciences in Spain:

a). As a new scientific field limnology is introduced in Spain relatively soon after it was defined by Forel in 1892 .

b). Later development of limnology is difficult because of lack of official support, being personal projects responsible for most of its limited achievements and resulting in a lack of continuity.

It is difficult to understand why a country where water is such a limited and therefore valuable resource has paid so little attention to the scientific study of continental aquatic ecosystems. Instead an engineering approach has dominated the understanding and management of Spanish waters, regarded almost exclusively as something to be stored in reservoirs and transported by channels, while ecological aspects have been largely ignored, and to a certain extent still are, by official authorities.

\section{ACKNOWLEDGEMENTS}

This article is part of a research project on the history of Spanish ecology partially supported by the Residencia de Estudiantes, Madrid.

\section{REFERENCES}

ALVAREZ COBELAS, M. \& T. GALLARDO. 1985. In memoriam. Pedro González Guerrero. Anales del Jardín Botánico de Madrid, 42 (1): 3-7.

AREVALO. C. 1914. El Laboratorio Hidrobiológico del Instituto de Valencia. Boletín de la Real Sociedad Española de Historia Natural, 14: 338-348.

AREVALO, C. 1916. Introducción al estudio de los cladóceros del plankton de la Albufera de Valencia. Anales del Instituto General y Técnico de Valencia, 1.

AREVALO, C. 1917. Algunos rotíferos planktónicos de la Albufera de Valencia. Anales del Instituto General y Técnico de Valencia, 2.

AREVALO, C. 1921. Sobre el concepto preciso de la palabra "hidrobiología", en su sentido estricto. Boletín de la Real Sociedad Española de Historia Natural, 21: 171-177.

AREVALO, C. 1923a. Algunas consideraciones sobre la variación temporal del plankton en aguas de Madrid. Boletín de la Real Sociedad Española de Historia Natural, 23: 94-103.

AREVALO, C. 1923b. El lago de Carucedo. Memorias de la Real Sociedad Española de Historia Natural, 11: 305-330.

AREVALO, C. 1929. La vida en las aguas dulces. Labor. Barcelona.

AZPEITIA, F. 1908. La diatomología española a comienzos del siglo XX. Asociación Española para el Progreso de las Ciencias. Congreso de Zaragoza IV (2): 5-320.

BUEN, O. de. 1887. Materiales para la fauna carcinológica de España. Anales de la Sociedad Española de Historia Natural, 16: 405-434.

CALDERON, S. 1888. La salina de Fuente-Piedra. Anales de la Sociedad Española de Historia Natural, 17: 72-83.

CALDERON, S. 1889. Excursión á Fuente-Piedra (parte zoológica). Anales de la Sociedad Española de Historia Natural, 18, Actas: 57-59.

CAMARASA, J. M. 1989. Aspectes histbrics dels estudis ecolbgics als Països Catalans. In: Historia Natural dels Països Catalans (R. FOLCH I GUILLEN, ed.) 14. Sistemas naturals: 25-40. Fundació Enciclopedia Catalana. Barcelona.

CISTERNAS, R. 1887. Ensayo descriptivo de los pe-ces de agua dulce que habitan en la provincia de Valencia. Anales de la Sociedad Española de Historia Natural, 6: 69-138.

DANTIN CERECEDA, J. 1929. Localización de las zonas endorreicas de España. Memorias de la Real Sociedad Española de Historia Natural, 15: 829-836.

DANTIN CERECEDA, J. 1940. La aridez y el endorreismo en España. El endorreismo bético. Estudios Geográficos, 1: 75-117. 
GOMIS BLANCO, A. 1988. Las ciencias naturales en España en el siglo XIX (1833-1874): morfología, fisiología y sistemática. Tesis doctoral, Facultad de Ciencias Biológicas, Universidad Complutense de Madrid. Madrid.

GRAELLS, M. P. 1846. Catálogo de los Moluscos Terrestres y de Agua Dulce observados en España. Imprenta Martínez. Madrid.

GRAELLS, M. P. 1864. Manual Practico de Piscicultura. E. Aguado. Madrid.

HALBFASS, W. 1913. Der Castañedasee, der grosste Süsswassersee Spaniens, und seine Umgebung. Petersen Mitteilungen, 59: 306-312.

MACHO VELADO, J. 1878. Moluscos de agua dulce de Galicia, con observaciones sobre las especies y localidades. Anales de la Sociedad Española de Historia Natural, 7:235-248.

MARGALEF, R. 1955. Los organismos indicadores en la Limnología. Instituto Forestal de Investigaciones y Experiencias. Madrid.

MARGALEF, R. 1974. Ecología. Omega. Barcelona. MARGALEF, R. 1983. Limnología. Omega. Barcelona. PARDO, L. 1942. La Albufera de Valencia. Estudio limnografico, biológico, económico y antropológico. Instituto Forestal de Investigaciones y Experiencias. Madrid.

PARDO, L. 1945. Nota necrológica. D. Celso Arévalo Carretero. Boletín de la Real Sociedad Española de Historia Natural, 43: 187-198.
PARDO, L. 1948. Catálogo de los lagos de España. Instituto Forestal de Investigaciones y Experiencias. Madrid.

PARDO, L. 1949. Breve noticia acerca de la Sección de Biología de las Aguas Continentales. Real Sociedad Española de Historia Natural. Tomo extraordinario publicado con motivo del LXXV aniversario de sufundación. 1946: 201-212.

PARDO, L. 1952. Para la historia de la Hidrobiología Española. El Laboratorio de Hidrobiología de Valencia. Boletín de la Real Sociedad Española de Historia Natural, 50: 407-415.

REYES NEVARES, S., dir. 1982. El exilio español en México. Fondo de Cultura Económica, Salvat Editores Mexicana. México, D. F.

REYES PROSPER, E. 1910. Las Carófitas de España, singular-mente las que crecen en sus estepas. Imprenta Artística Española. Madrid.

REYES PROSPER, E. 1915. Las estepas de España y su vegetación. Real Casa. Madrid.

TABOADA TUNDIDOR, J. 1913. El lago de San Martín de Castañeda. Boletín de la Real Sociedad Española de Historia Natural, 13: 359-386.

VELAZ DE MEDRANO, L. \& J. UGARTE. 1933. Estudio monografico del río Manzanares. Instituto Forestal de Investigaciones y Experiencias. Madrid.

WILLKOMM, H. M. 1852. Die Strand- und Steppengebiete der iberischen Halbinsel und dere vegetation. Friedrich Fleischer. Leizpig. 